\title{
Critiques of growth in classical political economy: Mill's stationary state and a Marxian response
}

\author{
GARETH DALE
}

\begin{abstract}
In recent political-economic theories of 'nature,' Mill and Marx/Engels form important reference points. Ecological economists see Mill's 'stationary state' as seminal, while Marxists have 'brought capitalism back in' to debates on growth and climate change, sparking a Marxological renaissance that has overturned our understanding of Marx/Engels' opus. This essay explores aspects of Mill's and Marx/Engels' work and contemporary reception. It identifies a resemblance between their historical dialectics. Marx's communism is driven by logics of 'agency' and 'structure' (including the 'tendency of profit rates to fall'). In Mill's dialectic a 'thesis,' material progress, calls forth its 'antithesis,' diminishing returns. The inevitable 'Aufhebung' is a stationary state of wealth and population; Mill mentions countervailing tendencies but fails to consider their capacity to postpone utopia's arrival. Today, Mill's schema lives on in ecological economics, shorn of determinism but with its market advocacy intact. It appears to contrast with the 'productive forces expansion' espoused by Marx/Engels. They stand accused of 'Promethean arrogance,' ignoring 'natural limits' and 'gambling on abundance.' But I find these criticisms to be ill-judged, and propose an alternative reading, arguing that their work contains a critique of the 'growth paradigm,' and that their 'cornucopian' ends do not sanction 'promethean' means.
\end{abstract}

That Karl Marx and John Stuart Mill inhabited the same city for over twenty years without encountering one another has prompted some of their admirers to compensate for the frustration of this event's unfortunate non-occurrence by means of fantasy. In Democracy: Crisis and Renewal, Paul Ginsborg (2008) conjures up two vigorous yet generally affable discussions between the two Victorian radicals. One, set in London in 1873, focuses upon democracy; the other is located in 'heaven' in 2008 and takes as its subject the worldly events unfolding below. Amartya Sen (2006) has likewise imagined meeting Mill and Marx in the afterworld, although he envisions the debate as proceeding more combatively, with his own avatar even feeling compelled to hide "behind an old-fashioned air raid shelter" to shield itself against the collateral damage. A more common enterprise has been to compare the work of the two thinkers, and treatises of this nature have been published on their theories of social conflict, on value theory, on equality, democracy and socialism. But such contributions have not been advanced on two interrelated issues that are of pressing concern in the current epoch: humanity's relationship to nature, and the means and ends of economic growth.

Both authors are important reference points in recent literature-academic and otherwise - on the political economy of 'nature.' Indeed, one of the welcome contributions of ecological economics, as it has developed over the last forty years, is that it has disinterred some of the ideas of classical political economy. ${ }^{1}$ Herman Daly (1977), for example, commends Malthus and Mill as one of the thinkers from whom we still have the most to learn. Daly is representative of a trend that commenced in the early 1970s, to frame solutions to problems of environmental degradation and resource depletion in the form of Mill's 'stationary state' - otherwise known as the 'no-growth economy' or 'equilibrium state' (Boulding 1973: 89; Meadows et al 1972: 171-5). Marx and Engels' critique of growth, and their theorisation of society-nature relations, have also received increasing attention in recent years. The 1980s and 1990s saw the publication of several books that developed

\footnotetext{
1 In a companion essay, Dale (2012b), I assess the work and influence on ecological thought of two other classical
} economists: Adam Smith and Thomas Malthus. 
Marxist approaches to ecological theory, notably David Harvey's Justice, Nature and the Geography of Difference and Carolyn Merchant's Radical Ecology. ${ }^{2}$ In recent years new publications have come thick and fast, with Jonathan Neale's Stop Global Warming (2008), Paul Burkett's Marxism and Ecological Economics (2009), Chris Williams' Ecology and Socialism, Peter Radt's Fetisch Wachstum, John Bellamy Foster, Brett Clark and Richard York's The Ecological Rift (all 2010), and, in 2011, Jonas Rest's Grüner Kapitalismus?, Ian Angus and Simon Butler's Too Many People?, Max Koch's Capitalism and Climate Change, and Patrick Bond's Politics of Climate Justice. These authors have simultaneously 'brought capitalism back in' to academic and lay debates on population, economic growth and climate change and have contributed to a Marxological renaissance that has led to important modifications in our conception of the Marx-Engels opus. In the latter regard, Bellamy Foster's Marx's Ecology (2000) was the ground-breaking text.

In this article I assess the work of Mill and Marx/Engels, and their contemporary reception. I explore their contribution to ecological political economy and survey the work of their contemporary devotees insofar as it relates to them. With regard to Mill, I identify a contradiction between the flourishing current interest in his 'stationary state' and the relative paucity of sober critical scrutiny, let alone philological inquiry, that has accompanied it. As to Marx and Engels, I interpret their work as a critique of growth, and suggest that their 'cornucopian' goals do not sanction 'promethean' means.

\section{John Stuart Mill and the dialectic of social progress}

In his Principles of Political Economy Mill performs an eyecatching manoeuvre. The textbook's initial passages adopt a familiar Whiggish tone, praising the "civilized nations" for their economic progress, which is characterised by "the perpetual, and ... unlimited, growth of man's power over nature" (1994: 66) and which affords scope "for an indefinite increase of capital, production, and population" (1994: 67-8). But it then backtracks, with a paean to the stationary state. Mill's thesis, notes Sheldon Wolin (1960: 321), represents a remarkable "inversion of one of the basic liberal postulates concerning history: instead of the belief that moral and intellectual progress depended upon unceasing material advance, true progress was identified with the stage when material growth had ceased." Less remarkable in his day but more so in ours is that Mill presents the termination of material growth as not only desirable but inevitable.

To an extent, Mill was picking up threads present in Smith, Malthus, and Ricardo. Under their guidance, political economy was being fashioned around the inescapable imperative of scarcity and the law of diminishing returns, the corollaries of which were "progressive impoverishment, the stunting of growth, and the possibility of reaching a stationary state" (Escobar 1995: 63). The latter was for them, in Daly's concise summary (2007: 117),

a real condition toward which the economy was tending as increasing population, diminishing returns, and increasing land rents squeezed profits to zero. Population would be held constant by subsistence wages and a high death rate. Capital stock would be held constant by a lack of inducement to invest resulting from zero profits thanks to rent absorbing the entire surplus which was itself limited by diminishing returns.

However, the stationary state figures in their thought only as a probable, and probably unpleasant, eventual destination, and all of them held out the prospect that technical

\footnotetext{
2 James O'Connor's Essays in Ecological Marxism deserves mention too, as do Elmar Altvater's The Future of the Market, Ted Benton's The Greening of Marxism, and Paul Burkett's Marx and Nature.
} 
advance would postpone its arrival, perhaps indefinitely. Smith $(1993: 81,91)$ held that some countries-he mentions China and Holland-may have already acquired their "full complement of riches," but he does not advocate this as an ideal, for life in a stationary state would be "dull." Ricardo (1973: 63) gave greater definition to the tendencies leading toward the stationary state but he regarded it as a "far distant" prospect, and even this is a comment made in passing, buried within a diatribe against the poor laws. Malthus, althoughfamously-the most pessimistic of the three, considers the possibility of stationary economies but insists that in the right conditions a country could "go on increasing in riches and population for hundreds, nay, almost thousands of years" (Malthus, 1989a: 437, 1989b: 43).

Mill drew upon his predecessors' theorems and speculations but knitted them together to construct a far-reaching and rigorous historical law. In essence, his is a dialectical formula that identifies a 'thesis', material progress, which calls into existence its 'antithesis', the law of diminishing returns, eventuating in the sublation of both trends in the stationary state. If the core of the 'antithesis' is the law of diminishing returns - which he hailed as "the most important proposition in political economy" - it contains in addition three subsidiary theses that, in combination, permit the prediction that the "kind of social progress characteristic of our present civilization" tends inexorably to reduce profit rates to a minimum (Mill 1994: 105-7). First, with increasing security of property, investment risk declines and consequently the level of profit deemed necessary to compensate for risk; second, as individuals gain maturity their capacity to defer gratification blossoms, resulting in declining consumerism and lower demand; third, as the world market becomes saturated and fewer 'new countries' enter it, opportunities for capital export decline. ${ }^{3}$ With profit rates on an unstoppable downward trajectory, and with population growth pressing against Malthusian limits, a stationary state of 'wealth' and population is ineluctable destiny.

For Mill's admirers his critique of the Ellenbogengesellschaft - a social order in which the normal condition of life is "struggling to get on," with much "trampling, crushing, elbowing, and treading on each other's heels" (Mill, in Hamilton and Denniss 2005: 172; see also Hamilton 2003 Chapter 1)-elicits unreserved praise, alongside his portrayal of the more comfortable life that its antithesis, the stationary state, will allow. ${ }^{4}$ In such a society, Mill ventures, technical progress would facilitate increased leisure time-unlike in the existing system in which it "serves no purpose but the increase of wealth." The social hierarchy would not be abolished but its gradient would be gentle.

Society would exhibit these features: a well-paid and affluent body of labourers; no enormous fortunes ...; but a much larger body of persons than at present, not only exempt from the coarser toils, but with sufficient leisure [...] to cultivate freely the graces of life, and afford examples of them to the classes less favourably circumstanced for their growth (Mill 1994: 129).

It would, in addition, feature a stationary population. In support of this proposition, Mill adduces a mix of arguments. Some are 'environmental' in character. In one passage he reasons (1994: 129) that the "unlimited increase of wealth and population" necessitates the cultivation of "every rood of land" and the ploughing of "every flowery waste or natural pasture", which leaves no room for human satisfaction in contemplating the "spontaneous activity of nature." It is, he adds (1994: 128), "not good for man to be kept perforce at all times in the presence of his species," for a world "from which solitude is extirpated, is a very poor ideal." Mill's other arguments concerning population are Malthusian. He was

This third point echoes Sismondi and anticipates Hobson and Luxemburg.

On 'trampling,' Mill's most recent biographer remarks: "It was easy for Mill to say this. His comfortable, highly paid job at the East India Company, obtained through his father, exempted him from the need for any trampling or elbowing" (Reeves 2007: 224). 
profoundly influenced by Malthus, commending the Surrey parson's population principle as a "great doctrine," one which he himself pursued "with ardent zeal" - even to the point of spending a night in jail for distributing birth control pamphlets (Mill 1909: 71; see also Collini 1993: 312). Yet Mill's Malthusianism was decidedly unorthodox. His identification of population growth "in the backward countries of the world" as legitimate, in contrast to the "advanced" countries where a "stricter restraint on population" is required (Mill 1994: 127), would raise eyebrows among Malthus' disciples today. And his argument for zero population growth rested in part on the claim that it would permit higher living standards. The social purpose of family planning was the achievement of "full employment at high wages to the whole labouring population through a voluntary restriction of the increase of their numbers" (Mill 1909: 71)-a goal of which the Surrey parson would hardly have approved.

Mill's thoughts on the stationary state attracted little comment from economistsMaynard Keynes, Kenneth Boulding and Lewis Mumford apart-until the 1970s. But since that decade it has become a common point of reference. As noted above, Daly $(1977,2007)$ cites Mill as a guiding star, as do numerous other ecology-minded economists (Rist, 2011). The Australian eco-philosopher Clive Hamilton (2003: xiv, 223-5, 231) commends to his readers a Millian Eden: a society guided by a "post-growth political philosophy of eudemonism," one that would "no longer worship" its industrialists and entrepreneurs and would cease to "sacrifice social justice and the environment on the altar of corporate profit." Tim Jackson, similarly, recommends the stationary state, and dismisses those who argue that capitalism requires growth by pointing to capitalist economies - he cites 1990s Russia as an example-that do shrink, thereby demonstrating the possibility of stabilising "a fairly conventional capitalist economy" at zero growth. He concedes that the stationary state is an ambitious goal, but with a "change of heart," an ethical commitment to frugality and "a healthy dose of repentance," all buttressed by environmental regulation and guided by "bright young economists," it is within our collective reach (Jackson 2009: 198, 239). ${ }^{5}$ Finally, in its 'Great Transition' report the Global Scenario Group, an environmental think tank, identifies Mill as the economist whose views are closest to recent thinking on transitions to a post-industrial society "based on human development rather than material acquisition" (Raskin et al.). It contrasts this Millian scenario, dubbed the 'New Sustainability Paradigm,' with a number of others, each of which is associated with a major economist: 'Market Forces' with Smith, 'Policy Reform' with Keynes, and 'Breakdown' with Malthus.

\section{Laissez-décroître; or, the hidden hand of diminishing returns}

Mill figures in the canon as the transitional figure between classical and neoclassical economics, and one reason for this is that he sought to cement the discipline's scientific credentials by defining its methodology in positivist and utilitarian terms. Political economy is an "abstract science," he would insist (2008: 45); it "is built upon hypotheses, strictly analogous to those which ... are the foundation of the other abstract sciences" such as geometry. The parsimony required for rigorous hypothesis formation is appropriate to economics because it concerns itself with man

solely as a being who desires to possess wealth, and who is capable of judging of the comparative efficacy of means for obtaining that end. It makes entire abstraction of every other human passion or motive; except those which may be regarded as perpetually antagonizing

\footnotetext{
For the purposes of this essay I consider only the treatment of the 'steady-state economy' within the 'Millian' environmental tradition, but other strands of discussion exist. See e.g. Mann (2013).
} 
principles to the desire of wealth, namely, aversion to labour, and desire of the present enjoyment of costly indulgences (Mill 2008: 41).

Although economists recognise that economic behaviour is conditioned by a plurality of motives, all its forms "are considered by Political Economy as flowing solely from the desire of wealth" (Mill 2008: 41).

Some, such as Serge Latouche (1993: 74), read Mill to be proposing that "multifaceted life" itself be reduced to "the single dimension of economic interests expressed in the marketplace," in the interests of shaping society into a "competitive machine." This is somewhat unfair. Mill's utilitarianism was more sophisticated than that of Bentham or Malthus, and was shaped by a richer and more liberal range of influences - from his partner and co-author Harriet Taylor's radicalism to Saint Simon, Carlyle, Coleridge and German Romanticism. Nonetheless, his programme did contribute indirectly to the outcome identified by Latouche, by confirming the exclusion of the physical environment from the economic calculus - for if only the ability to produce 'utility' matters, the physical aspects of different goods lose all relevance-and in the implicit ideological support it affords the capitalist mode of production. On the latter, Mill makes four crucial moves. First, he divides the sphere of production from distribution, deeming the former-in positivist, Malthusian fashion - to be governed by laws that are natural and "quite independent of the social or other economic arrangements that are made to accommodate them." 6 They simply form a relationship between human beings and the objects of nature "which is fixed by what is physically possible between the two" (Fine 1982: 23). Second, although he does admit the operation of "social laws" in the sphere of distribution he omits from consideration the central aspect of distribution in capitalist society: of the means of production to the employing class. Third, he justifies the institution of private-property in social-contract terms as having been blessed "by mutual agreement" (Mill 2008: 42), and its actual division in utilitarian terms, in 'labour justification' terms (private property is a means of according to individuals the proceeds of their labour), and in straightforward contractual terms - that property transactions signed without physical coercion or trickery simply should be honoured. ${ }^{7}$ Fourth, he rejects Ricardo's labour theory of value, replacing it with a conception of value that in effect reduces it to price. Profits, in his schema, arise from the employer's own labour and "abstinence." Wages are what an employer is prepared to pay for labour; their level reflects supply and demand. (Hence Mill's recommendation of zero population growth as a method for raising the living standards of the masses.)

As regards the stationary state, Mill's argument, as alluded to above, is that its arrival is inevitable. "When industrial progress ceases," he asks (1994: 124), "in what condition are we to expect that it will leave mankind?" Cease it must, for it is self-evident that "the increase of wealth is not boundless," that beyond "the progressive state lies the stationary state," and that each advance moves us closer to that terminus. This "ultimate goal," he continues, "is at all times near enough to be fully in view," such that "we are always on the verge of it." Yet then - tantalisingly - he remarks that "if we have not reached it long ago, it is because the goal itself flies before us." Why does it fly so? Because the tendencies that propel its approach are counteracted by others. Inventions and innovations improve the techniques of production, the education and training of the workforce permits higher productivity, while an "overflow of capital" from rich countries to "the uncultivated or ill-cultivated regions of the earth" delays the saturation of capital in the former (Mill 1994: 124-5). At this point in the argument one would expect Mill to pay serious consideration to

\footnotetext{
$6 \quad$ Although, following Thomas Malthus and David Ricardo, Mill adopted a positivist methodology, he drew a more subtle distinction between the methods of the natural and social sciences, and later in life he partially resiled from his earlier positivism.

Later in life he backtracked from the labour justification argument. See Medearis (2005).
} 
the question of whether the law of diminishing returns could be counterbalanced by tendencies of increasing returns, and whether consumerism and opportunities for capital export might expand instead of contract. But rather than pause to reflect upon these potential challenges to his historical dialectic, or whether the countervailing tendencies might be sufficiently weighty to indefinitely postpone the arrival of the stationary state, he merely restates that the latter is an "irresistible necessity."

These are by no means the only difficulties faced by Mill's thesis. There is also the small matter of the 'growth imperative.' The theorisation of economic growth was a central concern for classical political economy. Smith set the tone, arguing that growth is selfreinforcing, and it is good: it fulfils material needs, furthers human intercourse, and benefits society as a whole. Mill presents the most fully fledged of sceptical arguments, yet does not provide an explanation of the growth imperative. In passing, he alludes to one of its motors, geopolitical competition. "For the safety of national independence," he declares, it is essential that a country's productivity "should not fall much behind its neighbours." But he fails to trace the implications of this insight for his thesis on the stationary state. Relatedly, he neglects either to provide an alternative explanation for the development of the 'growth imperative' or to consider the idea that capitalism is inherently a 'growth economy,' i.e. an economy that is systemically geared to growth. Yet Mill gives unqualified support to its basic institutions-wage labour, market exchange, and private property in the means of production-as well as to laissez faire and free trade. Every restriction upon market competition "is an evil," he proclaims (1970: 142), and "every extension of it, even if for the time injuriously affecting some class of labourers, is always an ultimate good." 8 He doesn't pause to ponder whether the "disagreeable symptoms" of the Ellenbogengesellschaft - the "trampling and elbowing" mentioned above-could be induced by that same free-market competition which elsewhere in the same book he defends to the hilt. Nor does he address the potential hazards that would in all likelihood confront the growth slowdown that he predicts. This is a serious omission, for it is evident that in a market society, as Boulding (1973: 89) has pointed out,

there is a real danger that even the approach of a stationary state and the diminution of net investment could result in a very serious crisis of the kind which occurred in the United States between 1929 and 1932. What happened then was that a system of disequilibrating feedback got started. An initial decline in net investment reduced profits, which caused a further decline in net investment, which reduced profits further, and so on, until by 1932 net investment was practically zero and profits were negative.

A final set of difficulties concern the latent tensions between Mill's commitments to the stationary state, on the one hand, and to laissez-faire liberalism and individualism, on the other. As Mancur Olson has observed (1973: 8), no-growth societies would necessarily be characterised by a comparatively high degree of governmental or other collective action, with "stringent regulations and wide-ranging prohibitions against pollution and other external diseconomies." Mill does not explore the participatory-democratic possibilities that a stationary state might afford, but does promote a number of authoritarian measures to enforce population control. Unlike most reformers, he defended the separation of spouses in workhouses, and he was prepared to countenance legislation "to forbid marriage unless the parties can show that they have the means of supporting a family" (Mill 1869, emphasis added; Reeves 2007: 209). But he pays no serious attention to the connections between his proposals for population control and his thesis on the stationary state, nor does he confront

\footnotetext{
Emphasis added. This renders problematic the Global Scenario Group's presentation of Mill's worldview as antithetical to the 'market forces' model.
} 
the possible contradictions between his liberal-individualist commitments and the rationing, taxation and other policies that a stationary state would require.

Mill's blueprint, in short, comprises a knotty tangle of determinist and utopian argumentation, shot through with unexplored problems and contradictions. The determinism lies in his assumption that the projected falling rate of profit will act benignly, as a 'hidden hand' that brings the stationary state into being. The utopianism consists chiefly in his dismissal of the countervailing tendencies that he recognises were perpetually postponing its arrival, and his blithe disregard for the growth-promoting pressures of geopolitical and market competition. (In particular, István Mészáros (2008: 274) points out, Mill's discussion of distribution fails to recognise that its fundamental feature is the "exclusive distribution of the means of production to the capitalist class" - a class that is constrained by market competition to prioritise economic growth over other considerations, whether human need or environmental limits.) More generally, Mill's political-economic aspiration was to a stationary free-market semi-democratic socialism-where 'socialism' refers to the reform of capitalism rather than its overthrow (Reeves 2007: 466). As such, he is open to the charge of utopianism that Rosa Luxemburg levelled against the 'liberal socialists' of her day: that they imagined the malign social effects of capitalism could be abolished without suppressing the system itself (Burawoy 1990).

How do today's advocates of a Millian stationary state relate to Mill's own thesis? Essentially, they draw upon his critique of the Ellenbogengesellschaft and his liberal idealism while jettisoning the determinist argumentation. Hamilton's Growth Fetish is a representative example. While sharing Mill's final goal, he rejects the assertion that growth will die back of its own accord. This obliges him to explain its perdurability, which he does by way of the concept of a 'growth imperative,' or 'fetish'. His book on the subject (2003: 16) proposes that the growth fetish is the product of "a social structure," one that "skews the priorities of individuals," promoting a form of false consciousness. Individuals' preferences "do not develop 'outside the system'; they are created and reinforced by the system, so that consumer sovereignty is a myth." The question is therefore "not one of personal consumer choice versus elitist social engineering; it is one of corporate manipulation of consumer behaviour versus individuals in a society understanding what is in their real interests" (Hamilton 2003: 65). Hence, the growth fetish is the complement of a systemic socioeconomic drive to "the accumulation of wealth through profit seeking" (Hamilton 2003: 119). But at this point Hamilton's argument becomes circular. For he theorises the drive to accumulate capital as itself a product of "the core belief that human wellbeing is advanced above all else by increasing the quantity and quality of goods and services consumed by individuals"(Hamilton 2003: 119). The 'engine' of accumulation is nothing without its fuel: the productivist and consumerist ideology of growth. Individuals could and should elect to reject this mentality - for example, "a large proportion of the labour force can choose to work less" (Hamilton 2003: 237)-but they elect to remain trapped in the system. "Responding to the lures of the marketers, they choose the gilded cage and would prefer not to be told that the door is open" (Hamilton 2003: xiv). That individuals choose this system is in large part because of the structuration of choice, which itself is determined largely by 'the marketers' and other elite actors. This may be so, yet Hamilton then concludes (2003: 236) that "the distribution of power in society today" that accords such sway to those elite actors is itself "organised by... the growth fetish." If 'fetish' is defined broadly, as having excessive regard for the power of something, Hamilton runs the risk of fetishising the growth fetish.

Tim Jackson's case for a stationary state is constructed from related materials and suffers from similar shortcomings. Like Hamilton's, his explanation of the persistence of economic growth relies upon circular argumentation: "The imperative to sell more goods, to innovate continually, to stimulate higher and higher levels of consumer demand" -i.e. the growth imperative - "is driven forwards by the pursuit of growth" (Jackson 2009: 97). And 
like Hamilton, he accords an extraordinary degree of autonomy to the 'growth imperative'. It has, for example,

shaped the architecture of the modern economy. It motivated the freedoms granted to the financial sector. It stood at least partly responsible for the loosening of regulations, the overextension of credit and the proliferation of unmanageable financial derivatives (Jackson 2009: 21).

In the tradition of Mill, Hamilton and Jackson offer a critique of 'actually existing capitalism' while defending its core structures (wage labour, the market system, private property in the means of production) and rejecting any more radical proposals for its revolutionary transformation. Hamilton's programme

reaffirms a necessary role for public ownership, but it does not propose any expropriation of private property. It is anti-capitalist in the sense that it argues that society and governments should no longer cede special significance to the objectives or moral claims of the owners of capital (Hamilton 2003: 212).

In its essentials, this is a restatement of Millian liberal socialism: a defence of the existing market system and distribution of property coupled with an honourable refusal to kowtow to vested interests and advocating a cultural revolution that resurrects "the middle-class virtues of moderation and frugality" (Hamilton, 2011: 44). Investment banks and hedge funds apart, few capitalist businesses are likely to object to anti-capitalism of this sort. Protected from the threat of expropriation, Hamilton's manifesto would allow them to continue as before, plutocratically engineering the social and political order-growth imperative and all.

Jackson's prospectus is similar. He dismisses revolutionary political change-glibly, one might say - as nothing but a frenzied attempt to "tear down every institutional structure we can lay our hands on" (Jackson 2009: 172). He identifies pre-1990 Russia as an example of a "non-capitalist economy" that was in the grip of the growth drive. As such, it demonstrates the limitations of those who link the growth drive to the capitalist mode of production, but Jackson refrains from attending to arguments that theorised pre-1991 Russia as a form of state capitalism (Callinicos 1991; Dale 2004, 2011), and he cites Russia's post1991 experience as proving that a capitalist economy can survive without growth, without referring either to the social catastrophe that unfolded under Yeltsin or to the question of whether degrowth on the international scale could replicate Russia's national 'success' on this front. Nor does he confront the fact that an even more calamitous collapse in 1990s Russia was thwarted thanks to loans that were predicated on the prospect of a resumption in growth-not a few of which flowed into the hydrocarbons sector. For an economy to 'degrow' over the longer run, interest payments must cease (for they require capital to expand), and the shock waves of this would self-evidently tear through the finance industry, the pensions industry, and beyond. Growth, as Ted Trainer recently remarked (2011), is not "like a faulty air conditioning unit, which can be taken away and the rest of the house will function more or less as it did before."

In sum, it is fair to describe John Stuart Mill's stationary state as a remarkable departure in classical political economy and a distinguished addition to the literature of utopia. But it fails to explore, let alone convincingly provide a pathogenesis of, capitalist society's 'growth pains.' In this respect it is followed by latter-day Millians such as Daly, Jackson and Hamilton. They offer many sensible and not a few acute criticisms of the growth imperative but lack precision in locating its driving force, and rely too often upon circular argumentation and wishful thinking. If Mill's legacy contains such manifest shortcomings in respect of the political economy of the environment, and lacks a critique of 
the growth paradigm, to what extent may this be said of his near-neighbour Karl Marx and his collaborator Friedrich Engels?

\section{Marx and Marxism: Beyond Prometheus and Pandora}

In terms of their influence on contemporary environmental debate, Marx and Engels have arrived later than Mill, but recent decades have witnessed a renaissance of Marxist ecological theory. Within this broad area of interest, I would like to pick out two currents. One, of which James $\mathrm{O}^{\prime}$ Connor and Ted Benton are prominent representatives, identifies within the classical Marxist tradition a clash of 'promethean' and 'eco-centric' principles. On the 'promethean' side, Marx and Engels are said to have advocated the conquest of nature by man, a quest that they saw as indispensable to the onward march of human progress, as registered by the expansion of the 'productive forces' - taken by some as a synonym for economic growth. Capitalism, they held, should be abolished on the grounds that it fetters the advance of the productive forces, for human society has a pressing interest in their 'unfettering', a development that Communist society would enable and accelerate, without serious regard to the environmental costs this would entail. In O'Connor's reading (1998: 38), Engels was susceptible to "technological fetishism," while Marx was guilty of ignoring the economic implications of thermodynamics - thus, he "brushed off Sergei Podolinsky, the first ecosocialist who thought that a specifically physical nature figures in value theory" (O'Connor 1998: 43, 122)..$^{9}$ Common to both Marx and Engels was a failure to place

ecological destruction at the center of their theory of capitalist accumulation and socioeconomic change. They underestimated the extent to which the historical development of capitalism has been based on the exhaustion of resources and degradation of nature ( $\mathrm{O}^{\prime}$ Connor 1998: 124).

Others have fleshed out the case. Ted Benton (1989), for example, diagnoses Marx and Engels as suffering from a "blindness to natural limits." Daniel Bensaïd (n.d.) opines that their refusal to incorporate "notions of thresholds and limits" smacks of "Promethean arrogance," adding that, carried away by the logic of their polemics against Malthus, they had "gambled on abundance as the solution to the world's problems." Similarly, Michael Löwy (in Foster, 2000: 135) charges that Marx adopted an "optimistic, 'promethean' conception of the limitless development of the productive forces," a conception that is "totally indefensible ... above all from the standpoint of the threat to the ecological balance of the planet."

In an influential treatise, The Enemy of Nature (2007), Joel Kovel has extended the argument. Marx and Engels' promethean productivism was, he maintains, was shared by "almost the entire socialist tradition, including those branches of it unburdened by Stalinism." Almost without exception, socialists have failed to "appropriate an ecocentric attitude," with many of them evincing an outright "enmity toward nature" (Kovel 2007: 231). As examples he highlights Lenin and Trotsky, whose "worship of technology" was no less than "messianic." In their utopia,

a heroic Bolshevism redeems fallen humanity. The gruesome outcome is well known: After Stalin's accession to power in 1927, ... whatever democratic impulses had endured through the early period of the Bolshevik regime were jettisoned, and the entire might of Soviet society was concentrated on building the forces of production for all-out accumulation. ${ }^{10}$

\footnotetext{
$9 \quad$ O'Connor, James (1998) Natural Causes; Essays in Ecological Marxism, New York: Guilford, pp.43, 122.

10 Kovel (2007: 224). In Kovel's peculiar reading, Stalin was the executor of Trotsky's policies as well as his executioner: "Trotsky's musings were given an official imprimatur, even as he was driven out."
} 
There were exceptions to the rule, but they were few; Kovel (2007: 226) namechecks William Morris and Rosa Luxemburg. In Luxemburg's case, he perceives in her sympathy with the suffering of animals an "authentically ecocentric way of being" -for example in her description of her feelings when witnessing guards beating a buffalo.

The beast looked at me, the tears welled from my own eyes ... The suffering of a dearly beloved brother could hardly have moved me more profoundly than I was moved in my impotence in the face of this mute agony (in Kovel 2007: 226).

When Luxemburg felt for the buffalo she was being receptive to its anguish. Marx, Engels and the Bolsheviks, by contrast, view nature-including animals-through Cartesian eyes, as inert matter to be understood solely as a resource available for appropriation by human labour. Failing to perceive the validity of a receptive attitude, their work is marred by a foreshortening of nature's intrinsic value (Kovel 2007: 232-3).

O'Connor, Benton and Kovel find rich resources in the theorisation of human society's relationship to nature by Marx and Engels and their followers, but they believe their method to be gravely damaged by an irreconcilable contradiction between its ecocentric and productivist/promethean commitments. Marx's method therefore requires radical reconstructive surgery, a project that is exemplified by $\mathrm{O}^{\prime}$ Connor's ambitious reworking of Marx's crisis theory. O'Connor (1998: 125, 307) bases his ecological crisis theory upon the concept of the conditions of production, defined "in Polanyi-like terms to include everything that is not produced as a commodity but that is treated as if it is a commodity." These conditions of production-including nature, urban space and infrastructure, community and labour power-do not respond to the normal operation of the law of value, and responsibility for their supply, use and quality are typically assumed by states. Although Marx did analyse the degradation and despoliation of some of these conditions - notably the quality of soil-under capitalist conditions, he failed to consider that this might raise the costs of the elements of capital and thereby give rise to economic crisis. O'Connor (1998: 167) seeks to supplement and enrich Marx's crisis theory by showing that capitalist relations, in undermining the natural conditions of production ("people and places and profits"), tend to produce crises of underconsumption and open up new possibilities for social transformation.

O'Connor's thesis is a formidable exercise in the critical development of Marx's work, but it is not without shortcomings. Some of these have been identified by Burkett and Bellamy Foster. The sharp line that $\mathrm{O}^{\prime}$ Connor draws between barriers to accumulation that are 'internal' to capitalist production relations and those that follow from the degradation of nature is, suggests Burkett (1999b), exaggerated, even "artificial," for the root of the destruction of nature and the exploitation of labour are at bottom one and the same. To this, Bellamy Foster adds two criticisms. One is that $\mathrm{O}^{\prime}$ Connor attempts to push too much into the "locked box" of economic crisis theory and consequently downplays the "full dimensions of the ecological crisis and even of capitalism's impact on the environment" (Bellamy Foster 2002). The other is that to assume that ecological degradation tends to undermine the accumulation process is to

underestimate capitalism's capacity to accumulate in the midst of the most blatant ecological destruction, to profit from environmental degradation, and to continue to destroy the earth to the point of no return. ... In other words, the dangers of a deepening ecological problem are all the more serious because the system does not have an internal (or external) regulatory mechanism that causes it to reorganize. There is no ecological counterpart to the business cycle (Bellamy Foster 2002). 
Bellamy Foster and Burkett are the most prominent representatives of an alternative approach to that developed by $\mathrm{O}^{\prime}$ Connor, Benton and Kovel, one that regards the apparently 'anti-ecological' elements in classical Marxism as either the product of misinterpretation or as real flaws but of an ancillary nature, within a body of work that has an 'ecological' concern at its core. Rather than drastic reconstruction, for them the task that beckons Marxist scholarship is to engage in philological research to build a fine-grained picture of Marx and Engels' ecological theory. In the process, they have sought to refute a number of empirical claims made by $\mathrm{O}^{\prime}$ Connor and others - for example, that Marx failed to integrate into his economic analysis the new notions of energy and entropy that followed from the discovery of the first and second laws of thermodynamics. ${ }^{11}$ In my view, Foster and Burkett's approach is the more persuasive, and in the rest of this essay I seek to add some points of detail, by way of analysis of the concepts of 'Prometheanism,' the 'domination of nature' and the 'gamble on abundance,' as well as 'progress' and the 'productive forces.'

To begin with the 'Promethean' relationship to nature that is attributed to Marx and Marxists, in its loose sense the attribution is uncontroversial, for it denotes a conception of human beings as a world-transforming species, one whose social activity manifests a continual striving to overcome its own limitations. The communist society to which Marx and Engels aspired was indeed predicated on an understanding of human beings as a needsexpanding species, and Marx explicitly criticised the 'Spartan', levelling-down, communist alternative, for it sets itself "a definite, limited standard" (Hughes 2000: 183). It is also incontrovertible that their 'promethean' optimism at times bordered on the naïve-for example in the exuberant claim made by the young Engels (1844), in his first economic manuscript, that "the productivity of the soil can be increased ad infinitum by the application of capital, labour and science."

That said, the charges of Bensaïd and Löwy, quoted above, are exaggerated. Consider the "gamble on abundance." Marx's best-known quote on the requirement of abundance is contained in his Critique of the Gotha Programme. It reads as follows. "When the individual is no longer subordinated within the division of labour," and when labour

has ceased to be merely a means of sustaining life and has become the prime necessity of life; when, in the train of the all-round development of individuals their productive powers have also increased and all the wellsprings of co-operative wealth flow more strongly-only then can ... society inscribe on its banner: from each according to his ability, to each according to his needs! (Marx 1875).

This is my own translation, for the standard one is misleading. It reads: “...when, together with the all-round development of the individual, the productive forces have also increased, and all the springs of social wealth flow abundantly-only then [etc.]." The differences are subtle but significant. In the original German the 'productive powers' cannot be understood as abstract forces but are unambiguously embodied in human beings, while abundant (or, to be precise, "more cooperatively wealthy") production is a relative, not an absolute state, and is merely one of the preconditions of a communist society (cf. Hughes 2000).

The reason Marx and Engels stipulate that a relatively high level of 'cooperative wealth' is indispensable to the creation of a communist society is that it is a prerequisite for the implementation of the principle of distribution according to need. The 'needs' of which they speak are not reducible to material 'urges,' or to selfish or instrumental desires, or to

\footnotetext{
11 See Burkett (2006), and Foster Clark and York (2010: 59). Burkett shows that Marx and Engels took Podolinsky's seriously, criticized its energy-reductionist elements, "pointed out the need to take fuller account of the depletion of nonrenewable energy sources in human production, and highlighted Podolinsky's failure to fully integrate environmental and classrelational concerns." He shows, moreover, that "Marx applies a metabolic-energy approach to capitalist exploitation that recognises both conservation of energy and matter-energy dissipation." Further, he demonstrates "that open-system thermodynamic and metabolic considerations are absolutely central to Marx's analysis of machinery and large-scale industry."
} 
'basic needs'. They are not, the Analytical Marxist Jonathan Hughes (2000: 181) explains, "simply the conditions for the existence of human beings, but the conditions for their existence as human beings; the conditions for a recognisably human way of life." A fully human existence requires the satisfaction of needs over and above the 'basic' needs of survival. Yet this, Hughes continues (2000: 188), is a matter

not so much of what should be produced as how productive activity should be conducted. Marx's resistance to an excessive emphasis on the satisfaction of basic needs arises not so much from a wish for increased material consumption as from concern about the distortion of human nature that occurs when human activity becomes a mere means to the satisfaction of 'animal' needs.

Moreover, needs are understood in the wider context of human flourishing, which includes, and rests upon, our relationship with nature.

These reflections impinge upon our understanding of the 'domination' or 'mastery' of nature that Marx and Engels (and Lenin and Trotsky - and, if more crudely, Mill12) endorsed. The concepts have more than a hint of the macho but, as Reiner Grundmann observes (1991), they make sense "only with respect to interests and needs. ... A society that does not take into account the repercussions of its transformation of nature can hardly be said to dominate nature at all." Marx's conception of the mastery of nature is one aspect of his notion of human flourishing and self-development, of humans unfolding their latent powers, and transforming themselves in the process of transforming nature. It refers, centrally, to the development of scientific method and technique that enable an enhanced understanding, recognition and acceptance of natural laws. As when the term mastery is applied to a virtuoso violinist, it denotes conscious and expert control, including of the limits of both performer and instrument. Likewise, the mastery of nature "does not mean that one behaves in a reckless fashion towards it, any more than we suggest that a masterly player dominates her violin when she hits it with a hammer" (Grundmann 1991). To give a concrete example, the ever-increasing emissions of greenhouse gases are a sign of a mastery so one-sided and short-sighted as to be akin to playing violin with hammer. Climate change represents a momentous example of humanity learning the laws of nature but failing to apply them judiciously, and reveals the potential for human society's ability to control the natural environment to decrease, as the planet careers towards feedback-driven runaway warming.

Far from exhibiting a cavalier desire for man to dominate nature in disregard of 'limits and thresholds,' the scholarship of Bellamy Foster and Burkett, and also in many respects of Benton, O'Connor et al., reveals Marx and Engels to have exhibited "a deep concern for issues of ecological limits and sustainability" (Bellamy Foster 2000: 164). Far from being "unreceptive" to nature, Marx found it intolerable that "all creatures have been made into property: the fish in the water, the birds in the air, the plants on the earth" and urged that they too "must become free" (in Bellamy Foster 2000). His critique of alienation and his vision of the emancipatory content of the future communist society, as Benton points out (1992), "have as a central theme the full development of the aesthetic and spiritual dimensions of human relations to nature." In Capital, Marx insists (in Bellamy Foster 2000: 164) that the natural environment is a necessary part of wealth, which should be treated with the understanding that it is "the inalienable condition for the existence and reproduction of the chain of human generations." He paid close attention to specific, empirical aspects of humanity's interaction with its environment, arguing that cash crop production stands in contradiction to the nature of agriculture itself, concerned as the latter

12 "The ways of Nature," declares Mill (1904), "are to be conquered not obeyed; her powers are often towards man in the position of enemies, from whom he must wrest ... what little he can for his own use." 
is "with the whole gamut of permanent conditions of life" required by human beings through the ages (Marx, in Bellamy Foster 2000: 164). He was a sharp critic of the devastating effects of deforestation, of the unsustainable way in which agricultural production is organised, and of the colossal and unnecessary wastefulness of manufacturing industry. His anthropology is based upon the premise that humans fashion their relationship to external nature through the production of their means of subsistence. As Grundmann (1991) reminds us, Marx employs the concept of 'metabolism' to define the labour process: "a process between man and nature, a process by which man, through his own actions, mediates, regulates and controls the metabolism between himself and nature" - a metabolism the disruption of which could spell disaster.

Similar points can be made with regard to Lenin and Trotsky. Presiding over a besieged, backward and impoverished country they inclined to a rather rose-tinted view of technological developments in the West, yet their inclusion on Kovel's blacklist of 'Enemies of Nature' is surely a case of mistaken identity. Kovel's charge sheet places a particular emphasis upon the ability of this or that Marxist personage to empathise with animals. To this author, it seems exaggerated, even if the general principle is persuasive-that empathy with fellow creatures is an important human capacity, and that the Taylorisation of animal husbandry exacerbates our alienation from the natural world, fostering ignorant and sentimental attitudes at the expense of empathy (Dickens 1996: 62ff; Berger 2009). If this principle is held as the standard of judgment, Lenin and particularly Trotsky may be found guilty of possessing a naïve faith in the benefits of agricultural mechanisation and standardisation, yet they appear much more 'receptive' to the natural world than Kovel allows. Trotsky was a connoisseur of nature, knowledgeable about the rarest of plants, and, in his Mexican exile, dutifully tending to the rabbits and chickens in the back yard (Deutscher 2003). Lenin's acquaintance with the ways of nature, and agricultural technique in particular, was remarkable. He appears "genuinely to have loved nature" and felt comfortable in the wild; there was little that he enjoyed more than long walks in the country (Weiner 2000: 23). More importantly, the government that he and Trotsky led, as Douglas Weiner (2000) has detailed, was committed to establishing conservation areas (in which shooting, harvesting, mining, woodcutting and tourism were all prohibited) and to promoting the study of conservation and the environment in Russia's schools.

But of the figures under discussion in this essay it was Engels who was most concerned and conversant with environmental issues. He inveighed repeatedly against the "squandering" of natural resources and warned, in an oft-quoted passage from the Dialectics of Nature (Engels 1876), of the unintended ecological consequences that result from social structures that reward short-term gain at the expense of other considerations.

What cared the Spanish planters in Cuba, who burned down forests on the slopes of the mountains and obtained from the ashes sufficient fertiliser for one generation of very highly profitable coffee trees - what cared they that the heavy tropical rainfall afterwards washed away the unprotected upper stratum of the soil, leaving behind only bare rock! In relation to nature, as to society, the present mode of production is predominantly concerned only about the immediate, the most tangible result; and then surprise is expressed that the more remote effects of actions directed to this end turn out to be quite different.

The same text also contains a celebrated passage that admonishes those who conceive of nature as something to be conquered.

Let us not flatter ourselves overmuch on account of our human conquest over nature. For each such conquest takes its revenge on us.... At every step we are reminded that we by no means rule over nature like a conqueror over a foreign people ... but that we ... belong to nature, and 
exist in its midst, and that all our mastery of it consists in the fact that we have the advantage ... of being able to know and correctly apply its laws.

Far from celebrating Prometheanism Engels is warning of its potential blowback - the evils that in Ancient Greek mythology are visited upon the world through Pandora's urn, in punishment of Prometheus. If Prometheus symbolises a 'productivist' wager on technological advance and Pandora's box its Romantic negation, Marx and Engels' philosophy of progress attempts to go through and beyond both, in a dialectical Aufhebung.

Let us examine this dialectic of progress in more detail. There are few better places to begin than Denis Mäder's meticulously documented and analysed Fortschritt bei Marx. Mäder (2010: 31, 122, 30 and passim) provides philological confirmation that Marx and Engels held a progress-regress model, with progress categorised as a "good," and did not construe progress as the march of history, comprising both 'light and dark' sides. (A classic example of the latter interpretation is Ronald Wright's thesis (2004) that "Progress has an internal logic that can lead beyond reason to catastrophe."13) Although certain of Marx's remarks can be read as supporting just such an 'ambivalence' model, it would be a mistake to do so, Mäder argues. For example, where Marx ventures that the "anarchy of production, ... the source of so much misery, is at the same time the source of so much progress" there is no question that misery and progress, despite their common source, are distinct (Mäder 2010: 107). Similarly, where he describes human progress under capitalism as resembling "that hideous, pagan idol, who would not drink the nectar but from the skulls of the slain" (Marx 1853) the metaphor presents the nectar as independent of the massacre and not its cause. (Nectar, after all, is not normally drunk from skulls.)

Historical progress, for Marx and Engels, is conceived in terms of the development of human beings as a social and natural species. The objective of social production should be "the human being," including "the working-out of his creative potentialities," and "human mastery over the forces of nature" (those of "so-called nature as well as of humanity's own nature"). The purpose of production, in this prospectus (Marx 1857-8), is not mere material goods but "the universality of individual needs, capacities, pleasures, productive forces etc." Marx (1857-8) contrasts these goals with what would nowadays be called the 'growth fetish' that develops within capitalist society, characterised by the appearance of production "as the aim of mankind and wealth as the aim of production" and the experience of the process of production as "total alienation," a society in which concrete human labour, and therefore human life activity and creativity itself, is subjected "to an entirely external end" - the abstract drive to expand exchange value.

According to Mäder (2010: 324), Marx and Engels identify two key criteria in their definition of human progress. One is 'politics', including social movements and political consciousness, i.e. human beings' recognition of their collective power to strategically intervene in the course of their history. The other is the development of productive forces. This concept is treated in the theory of historical materialism as non-problematic, and in Marx's analysis of capitalism he does tend to assume productive forces development to be roughly synonymous with an increase in labour productivity, but it is a term with a variety of referents, and cannot be equated with material economic growth (Hughes 2000). Essentially, it denotes the ways in which human beings work upon nature, developing their capacities and producing goods and services to fulfil their needs and wants. It refers to workers, their skills, knowledge and techniques, their ability to cooperate and their scientific knowledge, the technologies they deploy and the resources and other conditions they find in the natural environment (Marx 1976). Together, these determine the productivity of social

\footnotetext{
13 Wright seems to be confusing 'progress' with Sidney Pollard's definition of the Victorian ideal of progress. An identical
} conflation can be found in Purdey (2010: 65). 
labour, and its ability to deploy natural resources to human ends. Insofar as the term can meaningfully be applied to raw materials and energy, it refers to "the discovery of new resources, of techniques to increase the viability of marginal deposits, and of new uses to which raw materials can be put," rather than to the extraction of resources per se (Hughes 2000: 126).

At the most general level, Marx and Engels applaud the development of human capacities, including the productive forces. They conceive of human beings as developing, needs-producing creatures, with human nature seen as a process of overcoming and transcending its own limitations through social activity. The development of the productive forces, even under capitalism, enhances human potential; for example, the expansion of knowledge and science enables an improved understanding of society and nature as well the possibility to engage in critical research (Mäder 2010: 324). Under capitalism, however, the productive forces received "a one-sided development only, and became for the majority destructive forces," as Marx and Engels (1845) phrased it. Alongside the impressive "industrial and scientific forces" that capitalism has summoned into being, there exist simultaneously

symptoms of decay, far surpassing the horrors of the latter times of the Roman Empire. In our days, everything seems pregnant with its contrary: Machinery, gifted with the wonderful power of shortening and fructifying human labour, we behold starving and overworking it. The newfangled sources of wealth, by some strange, weird spell, are turned into sources of want. ... At the same pace that mankind masters nature, man seems to become enslaved to other men or to his own infamy. ... This antagonism between the productive forces and the social relations of our epoch is a fact, palpable, overwhelming, and not to be controverted (Marx, in Klingender 1943).

According to this infernal dialectic, even the mastery of nature turns into its opposite. "All progress in capitalist agriculture," as Marx puts it in Capital Volume One,

is a progress in the art, not only of robbing the workers, but of robbing the soil; all progress in increasing the fertility of the soil for a given time is a progress towards ruining the more longlasting sources of that fertility. . . Capitalist production, therefore, only develops the techniques and the degree of combination of the social process of production by simultaneously undermining the original sources of all wealth-the soil and the workers (Marx, in Moore 2000: 127).

These arguments are central to Marx and Engels' prognosis for social transformation. The development of the productive forces not only enhances the capacity of human beings to freely and collectively determine their fate but also, by entering into contradiction with the relations of production, yields the possibility of social revolution. The insistence upon the role of productive forces development in preparing the ground for communism, however, has attracted more than a little criticism. It is suggested that the claim that capitalist relations of production fetter the development of productive forces entails an argument that people have an interest in their 'unfettered' development regardless of the environmental costs involved. But this interpretation involves an indefensible distortion of Marx and Engels' case. For the motivating interest that they ascribe to people in replacing capitalism with communism is an interest in their own welfare, and that of human society generally. As I argued above, there is no reason to ascribe to them the view that communism would or should engage in ecologically damaging processes. Likewise, their enthusiasm for the expansion of human needs and powers is perfectly compatible with a reduction in resource use (Hughes 2000: 143). Indeed, in the Communist Manifesto Marx and Engels insist 
that the productive forces had already reached the stage at which their desired transition of mode of production could succeed - in 1848 !

\section{Demeter's mistaken identity: Marx, Engels and the growth paradigm}

Marx and Engels' critique of capitalism is commonly depicted as 'productivist' in character, in that it putatively centres on the system's failure to maximise output in a balanced way. As outlined above, the reasons to dissent from this depiction are many. But I would go further, and would suggest that their theory contains a critique of what is nowadays called the 'growth paradigm.'14 Fundamentally, the growth paradigm is the idea that economic growth is good, imperative, essentially limitless, and a matter of pressing concern for society as a whole. In addition, it relies upon two flanking assumptions that may appear self-evident but should nonetheless be stated: that 'an economy' exists as a definite entity, occupying a distinct dimension of society within which processes occur that can be meaningfully understood as parts of an articulated assemblage, rather than as a congeries of unrelated acts; and that aggregated 'economic' activities have in common some quantifiable substance that can be measured in order to ascertain whether 'the economy' is or is not growing. All of these aspects of the growth paradigm are subjected to critique by Marx and Engels. Although they lived before the term 'economic growth' had entered the lexicon and before the growth paradigm had achieved its complete form, a trenchant critique of it can be assembled from their writings, in particular from their analysis of capital's imperative to the relentless expansion of production for its own sake.

The axial concept in Marx's theory of capitalism is the contradiction between wealth (use value-anything that satisfies human needs) and its alienated form under capitalist conditions (value). He wasn't the first to identify contradictory aspects of this relationship. For example the Earl of Lauderdale noted the paradox that an increase in the scarcity of a good such as water would enhance 'private riches' (exchange values) at the expense of the common wealth (Bellamy Foster, Clark and York 2010: 55). But Marx was able to "make the Lauderdale paradox his own" by analysing generalised commodity production simultaneously in terms of value relations and material processes (Bellamy Foster, Clark and York 2010: 59).

Marx's value analysis provides a systematic diagnosis of the commensurability of value. In his theory, the substance of value is abstract labour; its measure is socially necessary labour time; its form of appearance is money. Through being exchanged, commodities are rendered commensurable: they "acquire a socially uniform status as values, which is distinct from their sensuously varied objectivity as articles of utility" (Marx 1976). In capitalist economies value relations prevail, such that unrelated acts are reduced to their exchange value and rendered commensurable, with value expansion being the goal of production. Whereas the classical economists took it as given that production is necessarily oriented to consumption, Marx, on the basis of his theory of value form, held that in capitalist production "what matters is not the immediate use-value but the exchange-value, and, in particular, the expansion of surplus-value." This is its driving force-and "it is a pretty conception that - in order to reason away the contradictions of capitalist production abstracts from its very basis and depicts it as production aiming at the direct satisfaction" of consumers (Marx, in Keen 2001). In this theory, competition drives capitals to expand, as if by coercive law. The heart of the accumulation process, as Colin Barker summarises Marx's argument,

$14 \quad$ For an extended discussion of the growth paradigm see Dale (2012); also Postone (1993: 309). 
is the continuous extraction of surplus labour using ever new methods, a process fuelled by the competitive relations existing among the various centres or units of accumulation, and constantly resisted by those subjected to it (Barker and Dale 1998).

The compulsive relationship between these two processes, competition and exploitation, provides the clue to understanding the singularly dynamic, crisis-ridden and environmentally damaging character of capitalism.

In a general sense, Marx (1992: 323) sees the basic contradiction of capitalist accumulation as that between the drive to the "absolute development of the productive forces, without regard to exchange value" and the imperative to "preserve existing exchange value." The first of these phrases may seem to endorse something akin to the growth paradigm, but the appearance deceives. As we saw above, Marx does not see the development of the productive forces as an unqualified good. Moreover, the paragraph that follows makes a clear distinction between two goals of production: capital accumulation, and social wellbeing.

Capital and its self-expansion appear as ... the motive and the purpose of production; production is only production for capital and not vice versa, the means of production are not mere means for a constant expansion of the living process of the society of producers. ... The means-unconditional development of the productive forces of society-comes continually into conflict with the limited purpose, the self-expansion of the existing capital (Marx 1894).

Placed in this context, the phrase that appears to support the absolute development of the productive forces, giving grist to those who accuse Marx of 'productivism,' reveals itself to be an aspect of a critique of capitalist economy for its growth fetishism.

The same insight - into the contradiction between use value and exchange value in a commodity-based system - upon which Marx and Engels's crisis theory is constructed also forms the kernel of their critique of humanity's relationship with nature in the capitalist mode of production. In their analysis values, expressed in money prices, are "homogenous, divisible, mobile, reversible, and quantitatively unlimited," in contrast to use values, which exist concretely as matter and energy in specific space and time and "exhibit qualitative variety, indivisibility, locational uniqueness, irreversibility and quantitative limits" (Burkett 2006: 168). The imperative of value expansion entails the subordination of the latter beneath the former, with profound implications both for the dynamics of capitalism and for the relationship between humanity and nature. Capital in Marx's theory, as Kovel (2007) points out, "is quantitative in its core, and imposes the regime of quantity upon the world." Because the paramount purpose of capitalist production is value expansion, use values (including land, raw materials, fuels and other natural resources) are treated simply as inputs contributory to that end, and their depletion and degradation do not show up on the bottom line. "Because individual capitalists are engaged in production and exchange for the sake of the immediate profit," as Engels reasoned (1876),

only the nearest, most immediate results must first be taken into account. As long as the individual manufacturer or merchant sells a manufactured or purchased commodity with the usual coveted profit, he is satisfied and does not concern himself with what afterwards becomes of the commodity and its purchasers. The same thing applies to the natural effects of the same actions.

In pursuit of surplus value, capitals are obliged to continually raise the rate either of absolute surplus value (by expanding production, cutting wages, lengthening the working day) or of relative surplus value (eg. by investing in new machines or other technology, or purchasing cheaper raw materials). Not only is a historically unsurpassed proportion of 
surplus product ploughed back into advancing productivity, but the scale of production tends to increase too. Capital accumulation brings in its wake

an ever more detailed subdivision of labour, an ever greater improvement of old machines, and a constant application of new machinery-a process which goes on uninterruptedly, with feverish haste, and upon an ever more gigantic scale (Marx 1847).

In short, Marx's political economy is intrinsically bound up with ecological processes. His argument is not only that human alienation from nature "is intrinsic to value's formal abstraction from use value," in Burkett's compressed formulation (in Williams 2010: 195), but also that "the value form of wealth by definition imbues production with an expansive character." Sustaining the process of capital self-expansion tends to require increasing supplies of natural materials and energy. In Capital, Marx shows that it was capitalist production relations, specifically the separation of workers from control over the tools of production, that enabled and encouraged the large-scale use of machinery (such as steam engines), a trend that synergised with the discovery of the fossil fuels by which they could be continuously powered (Keefer 2010; Burkett 2006). In these ways, Marx and Engels provide a critical theory of capitalism's growth imperative and of its tendency to render commensurable (and hence quantifiable) heterogenous economic processes. Yet they also advanced explanations of two additional elements of the growth paradigm: the notion that 'the economy' exists as a distinct sphere, and the fetish character of economic processes. They explain the first of these by reference to the exploitation relation that prevails in capitalism, the unique quality of which is that it is enforced primarily through the effect of propertylessness on the workers' 'voluntary' decision to hire out their labour-power rather than by direct coercion within structures of personal obligation or ownership. With marketisation there evolved a contractuallymediated 'private' realm, a separately institutionalised 'economic' sphere for the production and exchange of goods and services. Coeval and concomitant with this development, state power was reconstituted as if partitioned within its own space distinct from civil society the 'political state.'

The second, commodity fetishism, refers to the way in which economic processes, although fundamentally social relations between people, assume the appearance of objective necessity, due to the way in which social labour is mediated through market exchange. The upshot is that relations between people assume the illusory form of relationships between things, with markets appearing to gain an objective power that dominates the lives of individuals. With the determination of economic processes by exchange value appearing in this way as a natural fact, capital accumulation, and with it economic growth, comes to appear as essentially infinite and eternal. These two social phenomena-commodity fetishism and the institutional separation of politics from economics - combine to create a potent ideological impression: that the core dynamic of capitalist society, the accumulation drive, is not human-created but pulses, naturally, from 'the economy.' Capital accumulation and economic growth assume the guise of natural processes, such that their endpoint would connote the termination of humanity itself - an apocalyptic Menschheitsdämmerung, in Elmar Altvater's apt phrase (2005: 27).

Let me summarise the main argument. To interpret Marx and Engels as exponents of a 'promethean' productivism is an error. It is to mistake Prometheus for his first cousin and goddess of the harvest, Demeter. ${ }^{15}$ For the cornucopia that is Marx and Engels' goal cannot be achieved by promethean means - trickery, theft and the exploitation of fire (or its lowentropy hydrocarbon analogues). It is not an impossible abundance the pursuit of which will

\footnotetext{
15 'Prometheus' and 'cornucopia' are commonly conflated as symbols of an optimistic or rapacious relationship to the
} environment, but a distinction between the two can usefully be made. See e.g. Speth (2008); Hornborg (2001). 
smash nature's limits and release Pandora's evils into the world. Rather, it is a realisable future geared to the satisfaction of human needs, created by human social labour, with solidaristic political consciousness as precondition and midwife. From this vantage point, Marx and Engels' aspiration towards 'abundance' appears neither as techno-fetishising hubris nor as arrogance towards nature's limits, but is based rather on a valid recognition: that natural resources are appraised and engaged with by human beings politically and sociologically; that is to say, with particular social purposes and objectives that are inherently open to change. To aspire to a state of abundance - if I may adapt Harvey's (1996: 147) rebuttal of Malthus - is to maintain that human beings have the will, wit, and capacity to develop our state of knowledge, alter our social goals and technological mixes, to modify our material economic practices in accordance with the needs of humanity and of the biosphere.

\section{Conclusion}

In this essay I introduce and critique the views of John Stuart Mill, regarded by some as "the first 'green' economist" (Reeves 2007: 233) and suggest that despite their 'productivist' reputation the work of Marx and Engels provides insight into environmental political economy that remains useful today. There is no need to repeat that discussion, but in concluding I shall make one further observation. The contemporary publications by the Marxists discussed above, by and large, are characterised by a concern to elucidate realworld processes or to contribute to contemporary debates while at the same time showing a willingness to carefully parse the opus of their tradition's founders. Some Millians - notably Amartya Sen - have evinced a similar inclination to subject the work of their nineteenthcentury forebear to critical scrutiny, but the same cannot be said of those who take their cue from Mill's stationary state. ${ }^{16}$ An apposite recent example is contained in a book by Daly (2007: 62) in which he professes "to show that ecological economics has deep historical roots in classical economics (Adam Smith, Thomas Malthus, David Ricardo, and especially John Stuart Mill)" but does nothing of the sort.

There are various reasons why Marxists tend to show a greater awareness of the work of their forebears than do Millians. Unlike the liberal tradition, theirs is - as the name suggests-highly indebted to one or two individuals. An additional factor may be that Marxists have the good fortune (in this regard) to find themselves positioned outside the mainstream. Such circumstances tend to stimulate closer investigation of intellectual genealogy. To give a salient example, Marx and Engels provided a prognosis of the transition to communism that comprised logics of 'structure' (including the 'tendency of the rate of profit to fall') as well as 'agency' (class struggle, social movements). That communism never arrived prompted critics to vigorously press their contemporary followers to account for this apparent contradiction of the theory, upon which a voluminous literature arose that has greatly enriched their understanding not only of the matter at hand but of much else besides - and the debates discussed in this essay should be seen within that wider context. Compare this to Mill. He provided a prediction of a transition to the stationary state, one that comprised logics of 'structure' (diminishing returns) combined with ethical preferences (for higher living standards, the contemplation of nature, etc.). When the utopia failed to appear, at most a handful of critics recommended that his followers account for the apparent contradiction in the theory, and no large literature arose. Instead, numerous Millians continue to cite his nineteenth-century blueprint as if it has been unfurled on our breakfast tables in pristine condition. Some further critical inquiry would not go amiss.

16 Sen has engaged in detail with the work of Mill, but not on the question of the stationary state. E.g. Sen (2006). 
Altvater, E. (1993), The Future of the Market, (London: Verso).

Altvater, E. (2005), Das Ende des Kapitalismus, wie wir ihn kennen: Eine radikale Kapitalismuskritik, (Westfälisches Dampfboot).

Angus, I. and Butler, S. (2011), Too Many People? Population, Immigration, and the Environmental Crisis, (Haymarket).

Barker, C. and Dale, G. (1998), 'Protest Waves in Western Europe; A Critique of "New Social Movement Theory,"' Critical Sociology, 25 (1-2).

Bellamy Foster, J. (2002), 'Capitalism and Ecology: The nature of the contradiction,' http://monthlyreview.org/2002/09/01/capitalism-and-ecology

Bellamy Foster, J. (2000), Marx's Ecology: Materialism and Nature, (New York: Monthly Review Press).

Bellamy Foster, J., Clark, B., and York, R. (2010), The Ecological Rift: Capitalism's war on the Earth, (New York: Monthly Review Press).

Bensaïd, D. (n.d.), 'Marxisms, Theory, Yesterday and Today,' www.internationalviewpoint.org/spip.php?article1929

Benton, T., ed. (1996), The Greening of Marxism, (New York: Guilford).

Benton, T. (1989), 'Marxism and natural limits: An ecological critique and reconstruction,' New Left Review I/178.

Benton, T. (1992), 'Ecology, Socialism and the Mastery of Nature: A reply to Reiner Grundmann,' New Left Review I/194.

Berger, J. (2009), About Looking, (Bloomsbury Publishing).

Bond, P. (2011), Politics of Climate Justice: Paralysis Above, Movement Below, (University of KwaZulu-Natal Press).

Boulding, K. (1973), 'The Shadow of the Stationary State,' Daedalus 102(4).

Burawoy, M. (1990), 'Marxism as Science: Historical Challenges and Theoretical Growth,' American Sociological Review 55: 775-793.

Burkett, P. (1999a), Marx and Nature: A Red and Green Perspective, (Palgrave).

Burkett, P. (1999b), 'Fusing Red and Green,' Monthly Review, http://monthlyreview.org/1999/02/01/fusing-red-and-green

Burkett, P, (2009), Marxism and Ecological Economics, (Brill).

Callinicos, A. (1991), The Revenge of History: Marxism and the East European Revolutions, (Cambridge: Polity).

Collini, S. (1993), Public Moralists: Political Thought and Intellectual Life in Britain, 1850-1930, (Oxford: Oxford University Press).

Dale, G. (2004), Between State Capitalism and Globalisation: The Collapse of the East German Economy, (Peter Lang).

Dale, G. (2011), 'The transition in Central and Eastern Europe,' in Gareth Dale, ed., First the Transition, then the Crash: Eastern Europe in the 2000s, (London: Pluto Press). 
Dale, G. (2012a), 'The Growth Paradigm: A critique,' International Socialism, Issue 134 www.isj.org.uk/index.php4?id=798\&issue $=134$

Dale, G. (2012b), 'Adam Smith's Green Thumb and Malthus' Three Horsemen: Cautionary tales from classical political economy,' Journal of Economic Issues, December.

Daly, H. (1977), Steady-State Economics, (W.H. Freeman).

Daly, H. (2007), Ecological Economics and Sustainable Development, Selected Essays of Herman Daly, (Edward Elgar).

Deutscher, I. (2003), The Prophet Outcast: Trotsky 1929-1940, (London: Verso).

Dickens, P. (1996), Reconstructing Nature: Alienation, emancipation and the division of labour, (London: Routledge).

Engels, F. (1844), 'Outlines of a Critique of Political Economy,' Deutsch-Französische Jahrbücher, www.marxists.org/archive/marx/works/1844/df-jahrbucher/outlines.htm

Engels, F. (1876), Dialectics of Nature, www.marxists.org/archive/marx/works/1876/partplayed-labour/index.htm

Escobar, A. (1995), Encountering Development: The Making and Unmaking of the Third World, (Princeton University Press).

Fine, B. (1982), Theories of the Capitalist Economy, (Edward Arnold).

Ginsborg, P. (2008), Democracy: Crisis and Renewal, (Profile Books).

Grundmann, R. (1991), 'The Ecological Challenge to Marxism,' New Left Review I/187.

Hamilton, C. (2003), Growth Fetish, (Allen \& Unwin).

Hamilton, C. (2011), Requiem for a Species: Why We Resist the Truth about Climate Change. (London: Earthscan).

Hamilton, C. and Denniss, R. (2005), Affluenza: When too much is never enough, (Crow's Nest: Allen \& Unwin).

Harvey, D. (1996), Justice, Nature and the Geography of Difference, (Oxford: Blackwell).

Hornborg, A. (2001), The Power of the Machine: Global inequalities of economy, technology, and environment, (AltaMira Press).

Hughes, J. (2000), Ecology and Historical Materialism, (Cambridge University Press).

Jackson, T. (2009), Prosperity Without Growth: Economics for a Finite Planet, (London: Earthscan).

Keefer, T. (2010), 'Machinery and Motive Power: Energy as a substitute for and enhancer of human labor,' in Kolya Abramsky, ed, Sparking a Worldwide Energy Revolution: Social struggles in the transition to a post-petrol world, (Oakland: AK Press).

Keen, S. (2001), Debunking Economics: The Naked Emperor of the Social Sciences, (Annandale: Pluto Press).

Klingender, F.D. (1943), Marxism and Modern Art: An approach to social realism, www.marxists.org/subject/art/lit crit/klingender/ch05.htm

Koch, M. (2011), Capitalism and Climate Change: Theoretical Discussion, Historical Development and Policy Responses, (Palgrave). 
Kovel, J. (2007), The Enemy of Nature: The End of Capitalism or the End of the World? $2^{\text {nd }}$ edn, (London: Zed).

Latouche, S. (1993), In the Wake of the Affluent Society: An exploration of post-development, (London: Zed Books).

Mäder, D. (2010), Fortschritt bei Marx, (Berlin: Akademie Verlag).

Malthus, T. (1989a [1803]), An Essay on the Principle of Population, Vol. 1, edited by Patricia James, (Cambridge University Press).

Malthus, T. (1989b [1803]), An Essay on the Principle of Population, Vol. 2, edited by Patricia James, (Cambridge University Press).

Mann, M. (2013), 'The End May Be Nigh, But For Whom?,' in Georgi Derluguian, ed., Does Capitalism Have a Future? (Yale University Press).

Marx, K. (1847), Wage Labour and Capital, www.marxists.org/archive/marx/works/1847/wage-labour/ch09.htm

Marx, K. (1853), 'The Future Results of the British Rule in India,' www.marxists.org/archive/marx/works/1853/07/22.htm

Marx, K. (1857-8), Grundrisse www.marxists.org/archive/marx/works/1857/grundrisse/ch09.htm

Marx, K. (1875), Critique of the Gotha Programme, www.marxists.org/archive/marx/works/1875/gotha/index.htm

Marx, K. (1976), Capital, Vol.1, (Harmondsworth: Penguin).

Marx, K. (1894), Capital, Vol. 3, Part III, Chapter 15

www.marxists.org/archive/marx/works/1894-c3/ch15.htm

Marx, K. (1992), MEGA, II 4.2, (Berlin: Dietz).

Marx, K. and Engels, F. (1845), The German Ideology, www.marxists.org/archive/marx/works/1845/german-ideology/ch01c.htm

Meadows, D., Meadows, D., Randers, J., and Behrens, W. (1972), The Limits to Growth: A report for the Club of Rome's project on the predicament of mankind, (Washington D.C.: Potomac Associates).

Medearis, J. (2005), 'Labor, Democracy, Utility, and Mill's Critique of Private Property,' American Journal of Political Science, Vol. 49, No. 1.

Merchant, C. (1992), Radical Ecology: The search for a livable world, (London: Routledge).

Mészáros, I. (2008), The Challenge and Burden of Historical Time: Socialism in the Twenty-First Century, (New York: Monthly Review Press).

Mill, J. S. (1869), On Liberty, www.utilitarianism.com/ol/five.html

Mill, J. S. (1904 [1874]), On Nature, www.lancs.ac.uk/users/philosophy/texts/mill_on.htm Mill, J. S. (1909 [1873]), Autobiography, (P.F. Collier).

Mill, J. S. (1970 [1848]), Principles of Political Economy, Books IV and V, (Harmondsworth: Penguin).

Mill, J. S. (1994 [1848]), Principles of Political Economy and Chapters on Socialism, ed by Jonathan Riley, (Oxford: Oxford University Press). 
Mill, J. S. (2008 [1836]), 'On the Definition and Method of Political Economy,' in Hausman, Daniel, ed., The Philosophy of Economics: An Anthology, (Cambridge University Press).

Moore, J. (2000), Environmental Crises and the Metabolic Rift in World-historical perspective, www.jasonwmoore.com/uploads/Moore_Environmental_Crises_the_Metabolic_Rift_O_E_20 00_.pdf

Neale, J. (2008), Stop Global Warming: Change the World, (London: Bookmarks).

O'Connor, J. (1998), Natural Causes; Essays in Ecological Marxism, (New York: Guilford).

Olson, M. (1973), 'Introduction,' Daedalus, 102(4).

Postone, M. (1993), Time, Labor and Social Domination: A reinterpretation of Marx's critical theory, (Cambridge University Press).

Purdey, S. (2010), Economic Growth, the Environment and International Relations, (London: Routledge).

Radt, P. (2010), Fetisch Wachstum: Philosophisch-ökonomische Anmerkungen zur Logik des Kapitalismus, (ISP Verlag).

Raskin, P. et al. (2002), Great Transition: The Promise and Lure of the Times Ahead, (Boston: Stockholm Environment Institute).

Reeves, R. (2007), John Stuart Mill: Victorian Firebrand, (Atlantic).

Rest, J. (2011), Grüner Kapitalismus? Klimwandel, globale Staaten-konkurrenz und die Verhinderung der Energiewende, (VS Verlag für Sozialwissenschaften).

Ricardo, D. (1973), The Principles of Political Economy and Taxation, (London: J. M. Dent).

Rist, G. (2011), The Delusions of Economics: The misguided certainties of a hazardous science, (London: Zed Books).

Sen, A. (2006), 'Reason, Freedom and Well-being,' Utilitas, Vol. 18, Issue 1, pp.80-96.

Smith, A. (1993 [1776]), An Inquiry into the Nature and Causes of the Wealth of Nations, (Oxford University Press).

Speth, J. G. (2008), The Bridge at the Edge of the World: Capitalism, the environment, and Crossing from Crisis to Sustainability, (New Haven: Yale University Press).

Trainer, T. (2011), 'The radical implications of a zero growth economy,' Real-World Economics Review, No. 57.

Weiner, D. (2000), Models of Nature: Ecology, Conservation, and Cultural Revolution in Soviet Russia, (Pittsburgh University Press).

Williams, C. (2010), Ecology and Socialism, (Haymarket).

Wolin, S. (1960), Politics and Vision: Continuity and Innovation in Western Political Thought, (Boston: Little, Brown).

Wright, R. (2004), A Short History of Progress, (Edinburgh: Canongate). 